\title{
RELEVANSI BUDAYA “ NATING” DAN PERSEPSI MASYARAKAT KABUPATEN LAHAT TERHADAP POTENSI PENDIRIAN BAITUL MAAL WAT TAMWIL
}

\author{
Erdah Litriani \\ Universitas Islam Negeri Raden Fatah Palembang \\ Erdahlitriani_uin@radenfatah.ac.id
}

Abstract

Pawn or nating practices that often occur in the community can be said to bave elements of persecution, this is because the perpetrators are very forced to pawn their land, during the agreement period the landowner does not have the right to manage or cultivate and not get a part of the production or yield harvest. Then, at the end of the agreement the landowner must redeem the land with the same amount or amount at the time of the initial loan without obtaining a share of the profit from the crop itself. The culture of communication that exists in the community bas been going on for a long time and has become an ordinary custom and there is no problem solving from the Government, traditional institutions or other related parties. The concept of BMT (Baitul Mal wat Tamwil) can be presented in the districts of Labat, South Sumatra and even in sub-districts and rural areas. The concept of BMT is a syari'ah microfinance institution. The Community Based Research (CBR) approach is carried out by in-depth interviews with the people who conduct nating activities, in order to find the underlying factors for the community to carry out these activities and the problems often faced. Interviens were carried out with land / land owners, capital owners, and local authorities with authority and customary actors. And, discuss the right solution for the problems that often occur. The results of this study found that the community conducts the practice of pawning because there is a very urgent need, usually for medical expenses, the cost of education for children, additional money to renovate the house, additional money to buy gardens, many reasons behind the community to practice pawning. The public perception regarding the existence of the BMT strongly agrees because it can belp the community, especially the people whose fields are already pawned, the type of BMT / Cooperative desired by the community is the type of savings and loans that do not interest, and payments that can be paid during the harvest season. The cultural relevance of the potential for the establishment of BMTs, that BMT is expected to be a new offering for problems that have existed so far. With the establishment of BMT, it is hoped that it can become a new solution to the problems that exist in the community. The establishment of BMT is very relevant for the solution to the problem of "nating" culture in Labat District in general.

Keywords: Nating, Baitul Maal Wat Tamwil

\section{PENDAHULUAN}

\section{Latar Belakang}

Realitas yang terjadi di masyarakat yang sudah menjadi adat istiadat dan menjadi kebudayaan pada masyarakat tertentu, yaitu sesuatu yang telah dikenal oleh masyarakat dan telah menjadi kebiasaan di kalangan masyarakat tertentu baik berupa perkataan maupun perbuatan. ${ }^{1}$ Beberapa masyarakat desa yang ada di Kabupaten Lahat sering menggadaikan sawah, kebun, rumah ataupun ladang mereka kepada kerabatnya sendiri, tengkulak atau pemilik modal, kebiasaan masyarakat kota Lahat khususnya para petani ini dalam menggadaikan sawah, kebun ataupun rumah mereka dikenal dengan istilah nating.

\footnotetext{
${ }^{1}$ Kamil Muchtar,dkk, ‘Usul Fiqih’, Yogyakarta.PT Dana Bakti Wakaf, 1995, Hal 146
} 
Nating sudah berlangsung lama di Kabupaten Lahat, dimana pelakunya menatingkan (menggadaikan) sawah,ladang, kebun bahkan rumah mereka untuk memenuhi kebutuhan hidup mereka baik untuk konsumsi, menutupi biaya hidup baik sebelum masa panen maupun pada masa transisi, untuk keperluan produksi dan ada juga yang menatingkan sawahnya karena faktor-faktor lain. Karena adanya perilaku yang demikian, maka penulis merasa perlu untuk mengaitkan budaya perilaku nating dengan ekonomi Islam dan muamalah dengan tujuan agar praktik nating ini tidak bertentangan dengan hukum Islam dan jauh dari praktik riba dan sejenis nya, karena pada hakekatnya perilaku budaya yang selaras dengan ajaran Islam akan menghasilkan suatu produk yang dapat memberikan kebaikan untuk semua kalangan.

Survey awal di lapangan bahwa dalam praktek gadai atau nating yang sering terjadi dimasyarakat dapat dikatakan terdapat unsur penganiayaan,hal ini disebabkan karena pelaku nating sangat terpaksa untuk menggadaikan lahan milik mereka, selama dalam masa perjanjian pemilik lahan tidak memiliki hak untuk mengelola atau menggarap dan tidak mendapatkan bagian dari hasil produksi atau hasil panen. Kemudian, pada saat perjanjian berakhir pemilik lahan harus menebus lahan dengan jumlah atau besaran yang sama pada saat peminjaman awal tanpa mendapatkan bagian dari keuntungan hasil panen itu sendiri. Budaya nating yang ada dimasyarakat selama ini telah berlangsung sejak lamadan menjadi adat yang biasa dan belum ada problem solving baik dari Pemerintah, lembaga adat atau pihak terkait lainnya.

Dalam hukum adat sendiri gadai di artikan sebagai menyerahkan tanah untuk menerima sejumlah uang secara tunai, dengan ketentuan si penjual (penggadai) tetap berhak atas pengembalian tanahnya dengan jalan menebusnya kembali. ${ }^{2}$ Gadai adalah jaminan atas barang yang dapat di jual sebagai jaminan hutang, dan kelak nantinya dapat di jual untuk membayar hutang, jika yang hutang tidak mampu membayar hutangnya karena kesulitan. $^{3}$

Diperoleh informasi bahwa di beberapa Kelurahan di Kabupaten Lahat ini belum ada lembaga keuangan Perbankan maupun koperasi ataupun Lembaga Keuangan Mikro Lainnya yang dapat memfasilitasi/membantu petani mendapatkan pinjaman, sehingga kondisi inilah yang menyebabkan budaya "Nating" ini masih tetap bertahan. Konsep BMT (Baitul Mal wat Tamwil) dapat dihadirkan di daerah kabupaten kota Lahat Sumatera Selatan dan bahkan di kecamatan dan perdesaan.Konsep BMT sebagai lembaga keuangan mikro syari'ah, merupakan konsep pengelolaan dana (simpan-pinjam) di tingkat komunitas yang sebenarnya searah dengan konsep otonomi daerah yang bertumpu pada pengelolaan sumber daya di tingkat pemerintahan (administrasi) terendah yaitu desa.

Potensi pendirian BMT bertujuan untuk meningkatkan kualitas usaha ekonomi untuk kesejahteraan anggota pada khususnya dan masyarakat pada umumnya. Pengertian tersebut dapat dipahami mengingat BMT berorientasi pada upaya peningkatan kesejahteraan anggota dan masyarakat.Anggota harus diberdayakan (empowering) supaya dapat mandiri.Dengan sendirinya tidak dapat dibenarkan jika para anggota dan masyarakat menjadi sangat tergantung

2 Dadan Muttaqien, Aspek Legal Lembaga Keuangan Syari'ah, cet 1, Yogyakarta: Safira Insani Press, 2009 hlm.106-107

${ }^{3}$ Moh Rifa'I, Konsep Perbankan Syari’ah, Semarang: CV. Wicaksana, 2002, hlm. 89 
kepada BMT.Dengan menjadi anggota BMT, masyarakat dapat meningkatkan taraf hidup melalui peningkatan usahanya. ${ }^{4}$

Penelitian terdahulu lebih membahas dari segi hukum islam apakah praktek nating diperbolehkan atau tidak, belum ada solusi bagi pelaku nating dalam hal penyelesaian kebutuhan modal.

Rumusan masalah dalam penelitian ini adalah:

1. Bagaimana situasi masyarakat kabupaten Lahat yang melakukan kegiatan "nating"?

2. Bagaimana persepsi masyarakat terhadap potensi pendirian Baitul Maal Wat Tamwil di Kabupaten Lahat?

3. Bagaimana relevansi budaya nating terhadap potensi pendirian Baitul Maal Wat Tamwil di Kabupaten Lahat?

\section{LITERATURE REVIEW}

\section{Konsep "Rahn" (Gadai)}

Menurut pasal 20 ayat 14 dalam Kompilasi Hukum Ekonomi Syariah (KHES) menjelaskah bahwa "Rahn/gadai adalah penguasaan barang milik peminjam oleh pemberi pinjaman sebagai jaminan”.

Ar-rahn adalah menahan salah satu harta milik si peminjam sebagai jaminan atas pinjaman yang diterimanya. Barang yang ditahan tersebut memiliki nilai ekonomis. Dengan demikian, pihak yang menahan memperoleh jaminan untuk dapat mengambil kembali seluruh atau sebagian piutangnya. Secara sederhana dapat dijelaskan bahwa rahn adalah semacam jaminan utang atau gadai. ${ }^{5}$

\section{Rukun dan Syarat Rahn}

Rukun rahn ada empat, yaitu pemberi gadai (Rahin), penerima gadai (murtahin), barang jaminan (Marhun) dan Utang (Marhun Bihi). Sementara rukun rahn adlah dua pihak yang berakad, akad rahn, barang jaminan (marhun) dan utang (marhun bihi). Menurut Hanafiyah rukun rahn adalah ijab dan Kabul dari rahin dan murtahin. ${ }^{6}$

Syarat yang terkait dengan utang adalah, pertama, utang merupakan hak yang harus dibayar. Kedua, jumlah utang dapat tertutupi dengan nilai barang yang digadaikan. Dengan kata lain, jumlah utang tidak boleh melebihi nilai barang yang menjadi jaminan. Ketiga, hak utang harus jelas. Sedangkan, menurut kalangan Syafi'iyah dan Hanbaiyah mensyaratkan.pertama, utang merupakan utang yang tetap dan wajib dibayar oleh rahin. Kedua, utang harus mengikat kedua belah pihak. Ketiga, jumlah,ukuran dan sifat utang harus jelas diantara pihak yang berakad.

${ }^{4}$ Rustam Effendi, Produksi Dalam Islam. (Yogyakarta : Magistra Insania bekerjasama dengan MSI UII, 2003) cet I, hlm.12

5 Sayyid Sabiq, Fiqhus Sunnah (Beirut : Darul-Kitab al-arabi, 1987), cetakan ke8,vol.III,hlm.169;Abdurrahman al-Jaziry, al-Fiqh ala Madzahib al-Arba'ah (Beirut ; Darul - Qalam), Vol.II,hlm.305

${ }^{6}$ Abubakar Ahmad bin Hussain al-Baihaqi, Sunan al-kubra...,II/424, hadis nomor 11541 


\section{Pemanfaatan Barang Gadai}

Terkait pemanfaatan barang gadaian oleh orang yang menggadaikan, ada dua pendapat dari kalangan ulama. Mayoritas ulama, selain Syafiiyah berpendapat bahwa orang yang menggadaikan tidak boleh memnfaatkan barang gadaian, sementara menurut kalangan syafiiyah memperbolehkan pihak yang menggadaikan memanfaatkan barang gadaian selama tidak menimbulkan perselisihan dengan pihak penerima gadai.

Kalangan hanafiyah berpendapat bahwa pihak yang menggadaikan tidak boleh memanfaatkan barang yang telah digadaikannya, apapun jenis dan bentuk barang tersebut, baik endaraan, tempat tinggal dan lainnya, kecuali penerima gadai mengijinkannya. Hal ini juga berlaku bagi penerima gadai, dia tidak diperbolehkan memanfaatkan barang gadai atau jaminan kecuali diizinkan oleh pihak yang menggadaikan.

Kalangan hanbaliyah berpendapat sama dengan kalangan hanafiyah. Mereka tidak memperbolehkan bagi pihak yang menggadaikan untuk memanfaatkan barang gadai, kecuali seizing pihak penerima gadai. Karena barang gadaian pada dasarnya sedang dalam penahanan ditangan penerima gadai, maka pemilik barang atau pihak yang menggadaikan tidak boleh memanfaatkannya.

Kalangan malikiyah lebih ekstrim, bagi pihak yang menggadaikan tidak boleh memanfaatkan barang gadaian, meskipun pihak penerima gadai mengizinkannnya. Izin yang diberikan pihak penerima gadai itu membatalkan gadai. Bagi Malikiyah, memang memanfaatkan barang gadaian menjadi hak bagi pemilik barang, namun ia harus menyerahkannya kepada penerima gadai. Sementara kalangan syafii'iyah berpendapat bagi pihak pemilik barang berhak atas manfaat barang miliknya. Apa yang dihasilkan dari barang gadaian juga menjad hak pemilik barang.

Masalah yang kedua adalah mengenai pemanfaat barnag gadai oleh penerima gadai. Jumhur ulama, kecuali kalangan Hanbaliyah tidak memperbolehkan penerima gadai untuk memanfaatkan barang gadai.

Kalangan Hanafiyah berpendapat bahwa penerima gadai tidak diperbolehkan memanfaatkan barang gadai apapun bentuknya. Kecuali, mendapatkan izin dari pemilik barnag. Apabila penerima barnag memanfaatkannya, maka hukumnya sama dengan gasab, menurut sebgaian Hanafiyah apabila pemilik barang atau pihak yang menggadaikan mengizinkan, maka penerima gadai boleh memanfaatkannya secara mutlak. Sebagian mereka juga mengharamkan pemanfaatan barang gadai oleh penerima gadai apabila disyaratkan dalam akad.

Kalangan Malikiyah berpendapat, apabila pemilik barang atau pihak yang menggadaikan mengizinkan atau mensyaratkan maka boleh agi penerima gadai untuk memanfaatkan barang gadai apabila utang dalam akad gadai tersebut utang jual beli. Bila utang tersebut adalah utang qard, maka tidak boleh. Dalam melaksanakan gadai ada beberpa mekanisme yang harus diperhatikan atau dipenuhi, apabila mekanisme tersebut sudah dipenuhi maka pebuatan tersebut dapat dikatakan sah. Adapun mekanisme pelaksanaan gadai yaitu: Sigat Akad, Aqid (Subyek gadai), Marbun (obyek gadai). 


\section{Baitul Maal Wat Tamwil (BMT)}

BMT merupakan bentuk Badan usaha yang berbadan hukum Koperasi sehingga BMT sama-sama berdiri di bawah naungan Dinas Koperasi, namun secara operasional BMT dijalankan berdasarkan prinsip syari'ah.

Visi BMT adalah upaya untuk mewujudkan BMT menjadi lembaga yang mampu meningkatkan kuaitas ibadah para anggotanya, sehingga mampu berperan sebagai wakil Allah dibumi, memakmurkan kehidupan anggota pada khususnya dan masyarakat pada umumnya. Adapun misinya adalah membangun dan mengembangkan tatanan perekonomian dan struktur masyarakat madani yang adil berkemakmuran, berkesejahteraan, serta berkeadilan berdasarkan syariah dan ridha Allah SWT. Jadi, misis BMT ini tidak semata-mata mencari keuntungan tetapi lebih berorientasi pada pendistribusian laba yang merata dan adil sesuai dengan prinsip ekonomi syariah.

\section{Teori Sosiologi Ekonomi}

Stratifikasi Sosial Stratifikasi Sosial merupakan gelaja umum yang sering terjadi di masyarakat. Oleh karena itu seberapa komplekyna masarakat akan tetap ditemui ang namana straifikasi sosial. Pada zaman dahulu Arestoteles, pernah menyatakan bahwa didalam setiap Negara terdapa tiga unsur, yaitu mereka yang kaya sekali, mereka yang melarat dan mereka yang berada ditengah-tengahya. Hal itu sudah terbukti dari zaman-zaman terdahulu, hal ini semakin memberi gambaran dimana dalam kehidupan bermasyarakat akan didapakan lapisanlapisan atau strata atau susunan yang bertingkat.

\section{Teori Persepsi}

Persepsi merupakan obyek-obyek di sekitar yang ditangkap melalui indera dan diproyeksikan pada bagian tertentu dalam otak sehingga dapat mengamati suatu obyek (Husaini, 1978: 103). Persepsi, adalah inti komunikasi, sedangkan penafsiran (interpretasi) adalah inti persepsi, yang identik dengan penyandian -balik (decoding) dalam proses komunikasi (Mulyana, 2002: 167). Persepsi disebut inti komunikasi, karena jika persepsi tidak akurat tidak mungkin terjadi komunikasi yang efektif.

\section{Kemiskinan}

Kemiskinan dibagi dalam empat bentuk, yaitu:

a. kemiskinan absolut kondisi dimana seseorang memiliki pendapatan di bawah garis kemiskinan atau tidak cukup untuk memenuhi kebutuhan pangan, sandang, papan, kesehatan, perumahan, dan pendidikan yang dibutuhkan untuk bisa hidup dan bekerja,

b. kemiskinan relatif kondisi miskin karena pengaruh kebijakan pembangunan yang belum menjangkau seluruh masyarakat, sehingga menyebabkan ketimpangan pada pendapatan,

\section{METODE PENELITIAN}

Penelitian ini menggunakan penelitian kualitatif. Penelitian kualitatif menggunakan metode atau pendekatan community based research dan pendekatan kualitatif Deskriptif. Penelitian ini dilakukan di Kabupaten Lahat dengan pertimbangan bahwa Lahat merupakan sentra penghasil padi dan kopi di Sumatera Selatan.Komuditas tanaman 
pangan padi dan kopi menjadi perhatian dalam penelitian ini karena merupakan mata pencaharian utama petani di Kabupaten Lahat dan komoditasi ini sangat potensial untuk dikembangkan.Subyek dari penelitian ini adalah masyarakat di Kabupaten Lahat yang melakukan kegiatan Nating. Pendekatan Community Based Riset (CBR) dilakukan dengan cara wawancara mendalam kepada masyarakat yang melakukan kegiatan nating, guna menemukan faktor-faktor yang melatarbelakangi masyarakat melakukan kegiatan nating tersebut dan permasalahan yang sering dihadapi. Wawancara dilakukan dengan pemilik tanah / lahan, pemilik modal, dan pemangku setempat yang berwenang baik pemangku pemerintahan maupun pelaku adat. Serta, mendiskusikan solusi yang tepat bagi masalah-masalah yang sering terjadi.

\section{PEMBAHASAN}

\section{Budaya "nating" di kabupaten lahat}

Di dalam masyarakat Kabupaten Lahat sering kali terjadi transaksi utang piutang yang mana tanah dijadikan sebagai barang jaminan atas utang mereka. Menurut pengamatan penyusun praktek gadai dalam masyarakat tersebut terdapat hal yang bisa menyebabkan penggadai (pemilik tanah) rugi, karena penerima gadai sering kali mendapat keuntungan yang lebih besar dari pada uang yang dipinjamkan.

Seperti halnya praktek gadai yang ditemukan di kecamatan yang dimana Dalam pelaksanaan sistem gadai kebanyakan masyarakat lebih memilih tanah produktif yang dapat langsung dimanfaatkan sebagai obyeknya. banyak yang terjadi di Desa itu, bahwa lahan pertanian yang dijadikan jaminan dikelola oleh penerima gadai dan hasilnya pun sepenuhnya dimanfaatkan oleh penerima gadai sebelum utang dari pemilik tanah lunas terbayar. Itulah sebabnya pihak pemberi pinjaman lebih menginginkan tanah produktif sebagai jaminan agar dapat memperoleh keuntungan dari tanah tersebut.

Masyarakat di Kecamatan Kota Agung lebih memilih alternatif untuk meminjam uang yang menurutnya lebih mudah dan cepat yaitu dengan cara menggadaikan tanah sawah miliknya dibanding meminjam uang di bank. Dengan pertimbangan bahwa, untuk meminjam uang di bank harus melalui berbagai persyaratan hingga membutuhkan proses yang lebih lama untuk mendapatkan uang yang akan dipinjam. Sehingga, masyarakat dengan terpaksa akan merelakan sawahnya sebagai jaminan yang kemudian dikelola dan hasilnyapun akan dinikmati oleh penerima gadai sampai utangnya lunas terbayar. Tentunya hal ini akan sangat menguntungkan bagi pihak penerima gadai karena selain mendapatkan keuntungan dari hasil sawah, uang pokok yang dipinjam oleh pemberi gadai juga akan dikembalikan.

Fenomena praktek gadai terkait waktu pemanfaatan gadai di Kecamatan Kota Agung dilakukan tanpa adanya batasan waktu dalam menggadaikan lahan pertanian sawahnya. Sehingga seringkali mengakibatkan gadai tersebut berlangsung bertahun-tahun karena penggadai belum mampu untuk melunasi hutangnya. Kemudian dalam menetapkan jumlah uang yang akan dipinjamkan tidak boleh melebihi dari harga jual tanah sawah yang akan di gadaikan. Melihat praktik gadai yang dilakukan di Kecamatan Kota Agung tentu jauh berbeda dari praktek pelaksanaan gadai pada umumnya, pemegang gadai berhak menguasai benda yang digadaikan kepadanya selama kewajiban si berhutang belum lunas, tetapi ia tidak berhak mempergunakan benda itu. Selanjutnya ia berhak menjual gadai itu, jika si berhutang tidak bisa 
membayar hutangnya. Jika hasil penjualan gadai itu lebih besar dari pada hutang yang harus dibayar, maka kelebihan itu harus di kembalikan kepada si penggadai. Tetapi jika hasil itu tidak mencukupi pembayaran hutang, maka si pemiutang tetap berhak menagih piutang yang belum dilunasi itu.

Dalam praktek gadai tersebut murtahin (penerima gadai) mengambil manfaat dari tanah rahin. Dalam fiqh Mu'amalah dijelaskan bahwa Hak murtahin kepada marhun hanya pada keadaan atau sifat kebendaannya yang mengandung nilai, tidak pada penggunaan dan pemungutan hasilnya.

\section{Alasan melakukan praktek "nating"}

Alasan yang dikemukakan oleh masing-masing pelaku nating berbeda-beda, selain hasil panen sawah, terkadang gagal panen belum lagi untuk menutupi biaya-biaya operasional seperti: biaya untuk membajak, biaya pupuk, serta pemenuhan kebutuhan lainnya. Kemudian menggadaikan sawah karena terpaksa, untuk biaya berobat orang tua yang sakit-sakitan. Namun sampai akhir perjanjian pelunasan belum mampu untuk dilunasi.

Sebagian besar pendapatan masyarakat berasal dari pertanian. Sedangkan, pengeluaran masyarakat terkadang lebih besar dari pendapatan yang ada. Sehingga, masyarakat terpaksa untuk melakukan "nating" atau gadai kepada pemilik modal. Proses nating sawah milik masyarakat sudah berlangsung sejak lama.

Waktu yang disepakati tergantung kesepakatan dua belah pihak, dalam kasus pak samsuri melakukan gadai sawah hanya dalam jangka waktu 2 tahun, dan cara pelunasannya boleh dengan cara dicicil. Tetapi, dalam perjalanannya beliau baru sanggup melunasi gadai dalam jangka waktu 5 tahun. Sehingga, waktu sisa selama 3 tahun masih digunakan oleh pemilik modal untuk mengelola lahan.

Hal lain yang mendasari masyarakat melakukan gadai sawah atau nating karena untuk biaya pengobatan orang tua. Bapak jono berusia 52 tahun, menggadaikan sawah seluas 1 hektar digadai dengan emas 18 suku. Jenis gadai adalah "tating kuase" . tetapi bedanya, pemilik modal masih mengijinkan untuk menggarap sawah dengan hasil panen dibagi dua antara pemilik modal dan pemilik lahan. Serta, seluruh biaya pengeluaran dibagi dua, dan atas kesepakatan bersama.

Proses gadai yang dilakukan sama dengan proses lainnya yaitu ada saksi dan materai yang nantinya dilaporkan ke kepala desa. Perjanjian antara penating dan yang ditating tidak ada batas waktu dan boleh membayar dengan cara mencicil.

Manfaat yang dirasakan adalah uang yang didapatkan untuk memenuhi kebutuhan hidup karena saat itu kurang lebih 20 tahun lalu ada pembangunan sungai. Jadi, air irigasi berhenti/ tidak mengalir selama dua tahun sehingga hasil dari gadai sawah untuk kegunaan sehari-hari.

Orang yang memiliki sawah menggunakan uang untuk menating sawah atas suatu keperluan. Ada 2 jenis nating yang ada di masyarakat. 1). Tating kuase : sawah atau barang yang digadai diserahkan sementara kepada penating sebelum ditebus. 2). Tating sasih/Sewa, pemilik sawah tetap bisa mengelola sawahnya, tetapi setiap panen hasil yang didapatkan harus dibayarkan kepada pemilik modal (berupa beras atau sejumlah yang ditentukan diawal) kepada pihak penating, kesepakatan ini berlangsung selama pemilik sawah melunasi uang pinjaman. 
Beberapa alasan bagi pemilik modal bersedia membantu meminjamkan dananya kepada pemilik lahan juga berbeda-beda. Misalkan bapak mesri mengungkapkan bahwa merasa kasihan kepada pemilik sawah yang mebutuhkan dana dadakan untuk keperluan biaya pengobatan orang tuanya, tetapi ada juga pemilik modal yang menjadikan kebiasaan atau kebutuhan mendadak dari masyarakat ini sebagai kesempatan mendapatkan manfaat lebih dari pengelolaan lahan yang ada.

\section{Jaminan yang digadai dalam praktek "nating"}

Barang jaminan yang dijaminkan adalah sawah. Seperti sawah yang tergadai seluas 1 hektar dengan besaran gadai Rp.50.000.000,- dengan jenis "tating Kuase" dimana sawah seutuhnya dikerjakan atau menjadi hak dari pemilik modal. Manfaat yang di dapatkan selama melakukan nating adalah mendapatkan uang diawal untuk memenuhi kebutuhan yang mendadak, tetapi kerugian yang dirasakan sangat banyak, seperti pemilik sawah tidak bisa lagi mengelola sawahnya, karea dikesepakatan awal yang mengelola sawah adala pemilik modal. Dengan keadaan seperti ini penghasilan pak samsuri dari sawah tidak ada sedangkan beliau harus menyiapkan uang untuk menebus kembali sawahnya. Singkatnya, hal ini membuat masyarakat semakin miskin.

Hal lain yang mendorong masyarakat untuk melakukan gadai sawah atau nating karena untuk biaya pengobatan orang tua menggadaikan sawah seluas 1 hektar digadai dengan emas 18 suku. Jenis gadai adalah "tating kuase" . tetapi bedanya, pemilik modal masih mengijinkan untuk menggarap sawah dengan hasil panen dibagi dua antara pemilik modal dan pemilik lahan. Serta, seluruh biaya pengeluaran dibagi dua, dan atas kesepakatan bersama. Mayoritas masyarakat menjadikan sawah sebagai barang jaminan gadai, mengenai besaran uang pinjaman disepakati oleh kedua belah pihak. Dulu besaran taksiran gadai lebih ditentukan oleh pemilik modal. Kontrak atau akad ditulis diatas matera secara legal dan di saksikan oleh beberapa orang saksi, dan diserahkan ke kepala desa.

\section{Persepsi masyarakat terhadap potensi pendirian BMT}

Persepsi masyarakat mengenai keberadaan BMT sangat setuju karena dapat membantu masyarakat khususnya masyarakat yang sawahnya sudah tergadai, jenis BMT/ Koperasi yang diinginkan oleh masyarakat adalah jenis simpan pinjam yang tidak berbunga, serta pembayaran yang dapat dibayar pada saat musim panen.

Keberadaan BMT sangat diharapkan oleh masyarakat karena pinjaman tanpa bunga atau menggunakan sistem bagi hasil. Sedangkan, jika masyarakat melakukan pinjaman ke perbankan langsung proses dan syaratnya sangat rumit. Masyarakat banyak yang tidak paham mengenai prosedur peminjaman dana diperbankan.

Respon positif dari masyarakat mengenai keberadaan BMT menjadi hal yang potensial untuk dikembangkan. BMT di kabupaten ini sangat berpotensi dikarenakan mayoritas masyarakat beragama Islam, dan masyarakat menginginkan sistem pinjaman tanpa bunga, karena dirasakan selama ini sistem bunga sangat memberatkan dalam proses cicilan pinjaman. Kepercayaan adalah asas utama bagi lembaga keuangan untuk berkembang. Pertumbuhan secara kuantitas tanpa diiringi dengan kualitas membawa potensi kehancuran. BMT (Baitul Mal Watamwil) dituntut untuk menerapkan manajemen keuangan operasional dan penerapan 
nilainilai syariah dengan baik. Resiko keuangan yang terkandung dalam bisnis lembaga keuangan pada umumnya juga tidak dapat dinegasikan.

\section{Relevansi praktek "nating" terhadap Potensi pendirian BMT}

Rahn atau nating yang telah berjalan pada masyarakat di kabupaten Lahat selama ini sudah sesuai dengan prinsip rahn yang ada. Bahwa didalam akad telah terjadi kesepakatan antar kedua belah pihak, dan pelunasan barang gadai disesuaikan dengan jangka waktu yang telah disepakati, pelunasan jaminan gadai sesuai dengan jumlah yang dipinjam pada saat awal kesepakatan, yaitu: ketika meminjam dengan 18 suku emas, pada saat pengembalian atau pelunasan juga diukur dengan emas sebrat 18 suku.

Ada beberapa hal yang tidak sesuai dengan konsep rahn adalah pada saat jangka waktu kesepakatan telah selesai. Tapi, pihak pemilik sawah tidak mampu melunasi jaminannya, biasanya tidak ada atau tidak terjadi kesepakatan baru lagi. Sehingga, pemilik modal masih mengelola atau menggarap sawahnya. Dan pihak pemilik sawah tidak mampu berbuat banyak.

Relevansi budaya nating terhadap potensi pendirian BMT, bahwa diharapkan BMT menjadi suatu penewaran baru bagi permsalahan yang ada selama ini. Budaya nating yang ada dimasyarakat sudah berlangsung selama bertahun-tahun, pemilik sawah yang tidak memiliki modal atau memiliki kebutuhan mendesak tidak memiliki solusi lain. Kecuali, meminjam dana dari pemilik modal. Dengan danya pendiirian BMT diharapkan mampu menjadi sebuah solusi baru bagi permasalahan yang ada dimasyarakat. Pendirian BMT sangat relevan bagi solusi permasalahan budaya "nating" di Kabupaten Lahat pada umumnya.

\section{SIMPULAN}

\section{Simpulan}

Kesimpulan yang didapatkan dalam penelitian ini adalah:

1. Situasi masyarakat kabupaten Lahat yang melakukan kegiatan "nating"

Masyarakat di Kecamatan Kota Agung lebih memilih alternatif untuk meminjam uang yang menurutnya lebih mudah dan cepat yaitu dengan cara menggadaikan tanah sawah miliknya dibanding meminjam uang di bank. Dengan pertimbangan bahwa, untuk meminjam uang di bank harus melalui berbagai persyaratan hingga membutuhkan proses yang lebih lama untuk mendapatkan uang yang akan dipinjam. Sehingga, masyarakat dengan terpaksa akan merelakan sawahnya sebagai jaminan yang kemudian dikelola dan hasilnyapun akan dinikmati oleh penerima gadai sampai utangnya lunas terbayar. Tentunya hal ini akan sangat menguntungkan bagi pihak penerima gadai karena selain mendapatkan keuntungan dari hasil sawah, uang pokok yang dipinjam oleh pemberi gadai juga akan dikembalikan.

Pemilik sawah menggadaikan atau nating memiliki alasan yang berbeda-beda, pada umumnya adalah karena ada kebutuhan yang sangat mendesak, seperti biaya berobat, biaya pendidikan, dan biaya mendesak lainnya.

2. Persepsi masyarakat tentang penerapan Baitul Maal Wat Tamwil di kabupaten Lahat

Persepsi masyarakat mengenai keberadaan BMT sangat setuju karena dapat membantu masyarakat khususnya masyarakat yang sawahnya sudah tergadai, jenis BMT/ 
Koperasi yang diinginkan oleh masyarakat adalah jenis simpan pinjam yang tidak berbunga, serta pembayaran yang dapat dibayar pada saat musim panen.

Respon positif dari masyarakat mengenai keberadaan BMT menjadi hal yang potensial untuk dikembangkan. BMT di kabupaten ini sangat berpotensi dikarenakan mayoritas masyarakat beragama Islam, dan masyarakat menginginkan sistem pinjaman tanpa bunga, karena dirasakan selama ini sistem bunga sangat memberatkan dalam proses cicilan pinjaman. Kepercayaan adalah asas utama bagi lembaga keuangan untuk berkembang. Pertumbuhan secara kuantitas tanpa diiringi dengan kualitas membawa potensi kehancuran. BMT (Baitul Mal Watamwil) dituntut untuk menerapkan manajemen keuangan operasional dan penerapan nilai-nilai syariah dengan baik.

3. Relevansi budaya nating masyarakat Kabupaten Lahat terhadap potensi pendirian Baitul Maal Wat Tamwil (BMT)

Potensi pendirian BMT sangat relevan bagi solusi permasalahan budaya "nating" di Kabupaten Lahat. Bebrapa identifikasi yang ditemukan pada budaya nating adalah terdapat kesesuaian dengan konsep Rahn dan beberapa ada yang tidak sesuai dengan konsep Rahn. Rahn atau nating yang telah berjalan pada masyarakat di kabupaten Lahat selama ini sudah sesuai dengan prinsip rahn yang ada. Bahwa didalam akad telah terjadi kesepakatan antar kedua belah pihak, dan pelunasan barang gadai disesuaikan dengan jangka waktu yang telah disepakati, pelunasan jaminan gadai sesuai dengan jumlah yang dipinjam pada saat awal kesepakatan, yaitu: ketika meminjam dengan 18 suku emas, pada saat pengembalian atau pelunasan juga diukur dengan emas sebrat 18 suku.

Ada beberapa hal yang tidak sesuai dengan konsep rahn adalah pada saat jangka waktu kesepakatan telah selesai. Tapi, pihak pemilik sawah tidak mampu melunasi jaminannya, biasanya tidak ada atau tidak terjadi kesepakatan baru lagi. Sehingga, pemilik modal masih mengelola atau menggarap sawahnya. Dan pihak pemilik sawah tidak mampu berbuat banyak.

\section{Saran}

Bagi masyarakat yang melakukan praktek "nating" atau gadai diharapkan memperhatikan item-item kesepakatan awal. Supaya tidak merugikan salah satu pihak. Dan jika dalam jangka waktu yang telah disepakati belum mampu melakukan pelunasan maka perlu adanya kesepakatan baru atau membuat lagi perjanjian.Bagi pemangku kepentingan baik pemangku adat atau pernagkat pemerintahan untuk lebih memperhatikan permasalahan perekonomian yang di hadapi oleh masyarakat setempat. Mencarikan solusi usaha yang dapat dikembangkan atau mencarikan solusi peminjaman dana yang tepat. Bagi pemerintahan untuk solusi peminjaman dana yang berlandaskan syariah, BMT sangat potensial untuk dikembangkan. Bagi peneliti selanjutnya adalah mengembangkan penelitian dengan metode kuantitatif. 


\section{DAFTAR PUSTAKA}

Aliasman (2005) Pelaksanaan gadai tanah dalam masyarakat hukum adat Minangkabau di Nagari Campago Kabupaten Padang Pariaman setelah berlakunya pasal 7 UU No. 56/Prp/1960 program Pascasarjana Universitas Diponegoro (Thesis)

Dadan Muttaqien, Aspek Legal Lembaga Keuangan Syari'ah, cet 1, Yogyakarta: Safira Insani Press, 2009 .

Gregory S. C. Hine,The importance of action research in teacher education programs, dal am Design, develop, evaluate: The core of the learninenvironment. Proceedings of the 22nd Annual Teaching Learning Forum, 7-8 February 2013. Perth: Murdoch University.

bttp:// ctl.curtin.edu.au professional_development/conferences/tlf/ tlf2013/refereed/ hine.htm

Hanafi, Community based research, panduan merancang dan melaksanakan penelitian bersama komunitas, UIN Sunan Ampel Surabaya, 2015.

https://www.academia.edu/12007478/PERILAKU BUDAYA NATING GADAI PADA MASYARAKAT KOTA PAGARALAM ANALISIS DALAM PERSPEKTIF EK ONOMI ISLAM

Jannah S, Miftahul (2009) Perspektif hukum islam terhadap gadai tanpa batas waktu dan dampaknya dalam masyarakat desakertagena daya kecamatan Kadur Kabupaten Pamekasan UIN Sunan Ampel Surabaya.

Kamil Muchtar,dkk, 'Usul Fiqih', Yogyakarta.PT Dana Bakti Wakaf, 1995.

Moh Rifa'I, Konsep Perbankan Syari'ah, Semarang: CV. Wicaksana, 2002.

Muhammad Sholikul Hadi, 'Pegadaian Syariah,’ Jakarta: Salemba Diniyah, 2003.

Munir 'Praktik Gadai Sawah dan Implikasi Sosial Ekonomi'. Jurnal Ilmiah, Universitas Brawijaya, Malang.

Nunung Nursyamsiah (2015), Perspektif hukum islam terhadap gadai tanah sawah di desa compreng kecamatan compreng kabupaten Subang, Jawa Barat, UIN Sunan Kalijaga Yogyakarta.

Rustam Effendi, Produksi Dalam Islam. (Yogyakarta : Magistra Insania bekerjasama dengan MSI UII, 2003) cet I.

Santoso, Arfan (2014), Analisis hukum islam terhadap pemanfaatan tanah sawah gadai untuk penanaman tebakau di desa bajur kecamatan waru kabupaten Pamekasan, UIN Sunan Ampel

Sarah Banks,Community Based Participatory Research A Guide to Ethical Principles and Practice, Center for Social Justice and Community Action, Durham University, UK. 2012.

Sulaiman Rasjid, 'Fiqih Islam', Bandung, Sinar Baru Algensindo, Cetakan Ke-36, 2003. 